\title{
Treatment efficacy, treatment failures and selection of macrolide resistance in patients with high load of Mycoplasma genitalium during treatment of male urethritis with josamycin
}

\author{
Alexander Guschin', Pavel Ryzhikh', Tatiana Rumyantseva', Mikhail Gomberg² and Magnus Unemo ${ }^{3,4^{*}}$
}

\begin{abstract}
Background: Azithromycin has been widely used for Mycoplasma genitalium treatment internationally. However, the eradication efficacy has substantially declined recent decade. In Russia, josamycin (another macrolide) is the recommended first-line treatment for M. genitalium infections, however, no data regarding treatment efficacy with josamycin and resistance in $M$. genitalium infections have been internationally published. We examined the $M$. genitalium prevalence in males attending an STI clinic in Moscow, Russia from December 2006 to January 2008, investigated treatment efficacy with josamycin in male urethritis, and monitored the M. genitalium DNA eradication dynamics and selection of macrolide resistance in $M$. genitalium during this treatment.
\end{abstract}

Methods: Microscopy and real-time PCRs were used to diagnose urethritis and non-viral STIs, respectively, in males $(n=320)$. M. genitalium positive patients were treated with recommended josamycin regimen and treatment efficacy was monitored using quantitative real-time PCR. Macrolide resistance mutations were identified using sequencing of the 235 rRNA gene.

Results: Forty-seven (14.7\%) males were positive for M. genitalium only and most (85.1\%) of these had symptoms and signs of urethritis. Forty-six (97.9\%) males agreed to participate in the treatment efficacy monitoring. All the pre-treatment M. genitalium specimens had wild-type $23 \mathrm{~S}$ rRNA. The elimination of M. genitalium DNA was substantially faster in patients with lower pre-treatment M. genitalium load, and the total eradication rate was $43 / 46$ (93.5\%). Of the six patients with high pre-treatment $M$. genitalium load, three (50\%) remained positive post-treatment and these positive specimens contained macrolide resistance mutations in the 235 rRNA gene, i.e., A2059G $(n=2)$ and A2062G $(n=1)$.

Conclusions: M. genitalium was a frequent cause of male urethritis in Moscow, Russia. The pre-treatment M. genitalium load might be an effective predictor of eradication efficacy with macrolides (and possibly additional antimicrobials) and selection of macrolide resistance. Additional in vivo and in vitro data are crucial to support the recommendation of using josamycin as first-line treatment for $M$. genitalium infections in Russia. It would be valuable to develop international $M$. genitalium management guidelines, and quantitative diagnostic PCRs determining also M. genitalium load and resistance mutations (for macrolides and ideally also moxifloxacin) should ideally be recommended.

Keywords: Mycoplasma genitalium, Treatment, Treatment efficacy, Treatment failure, Antimicrobial resistance, 23S rRNA, Josamycin, Macrolides, Russia, Male urethritis

\footnotetext{
* Correspondence: magnus.unemo@orebroll.se

${ }^{3}$ WHO Collaborating Centre for Gonorrhoea and other STIs, National

Reference Laboratory for Pathogenic Neisseria, Örebro University Hospital,

Örebro, Sweden

${ }^{4}$ Department of Laboratory Medicine, Microbiology, School of Medicine,

Örebro University, Örebro, Sweden

Full list of author information is available at the end of the article
}

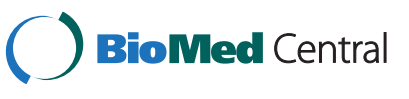

(C) 2015 Guschin et al.; licensee BioMed Central. This is an Open Access article distributed under the terms of the Creative Commons Attribution License (http://creativecommons.org/licenses/by/4.0), which permits unrestricted use, distribution, and reproduction in any medium, provided the original work is properly credited. The Creative Commons Public Domain Dedication waiver (http://creativecommons.org/publicdomain/zero/1.0/) applies to the data made available in this article, unless otherwise stated. 


\section{Background}

Mycoplasma genitalium has in recent decades been shown to be a frequent cause of urethritis in men and urethritis, cervicitis, endometritis, pelvic inflammatory disease, and possibly infertility in women. In patients with non-gonococcal urethritis (NGU), M. genitalium is commonly the second most frequent etiology, i.e., after Chlamydia trachomatis [1-6]. In the general population, the prevalence of $M$. genitalium ranges from approximately $1 \%$ to $3 \%$, and among men with symptomatic non-chlamydial, non-gonococcal urethritis (NCNGU), the prevalence ranges from $15 \%$ to $35 \%[1,7,8]$.

Still, no international management guidelines for $M$. genitalium infections have been published. The recommended treatments of male NGU in the European guideline include tetracyclines and macrolides [9]. However, despite being effective in vitro tetracyclines have shown a low eradication rate for M. genitalium clinically [1,10-13]. Azithromycin $1 \mathrm{~g}$ single oral dose has been widely used. However, despite that large, appropriate randomized clinical trials are lacking an extended azithromycin regimen has been indicated to be slightly more effective or at least equally effective in eradicating M. genitalium, i.e., azithromycin $500 \mathrm{mg}$ on day 1 followed by $250 \mathrm{mg}$ daily on days 2-5 [1,11,13-15]. Worryingly, the eradication rate of M. genitalium after azithromycin $1 \mathrm{~g}$ therapy has substantially declined during the last decade $[1,10,12-14,16]$. Recently, it was also reported that azithromycin $1 \mathrm{~g}$ therapy was associated with selection of azithromycin resistance in M. genitalium [14]. It was also most recently hypothesized that treatment failure can be associated with a higher load of M. genitalium in the clinical specimens [17]. M. genitalium strains resistant to azithromycin contain resistance mutations in region $\mathrm{V}$ of $23 \mathrm{~S}$ rRNA, which is encoded be a single copy gene in $M$. genitalium $[1,10,13,14,18]$. Moxifloxacin is the most commonly used second-line regimen in patients failing azithromycin therapy. However, the side-effects, cost, and the risk of selection of resistance limit the moxifloxacin use $[1,13,15,19,20]$.

In Russia, the 16-membered lactone ring macrolide josamycin (500 mg three times daily, 10 days) is the nationally recommended first-line treatment for M. genitalium infections and it is widely used mainly in the treatment of NGU, C. trachomatis infections and M. genitalium infections, including in pregnancy [21]. Josamycin is also included in the second-line treatment in the European C. trachomatis management guideline [22], however, in general josamycin is very rarely used in the majority of European countries. Despite that the in vitro susceptibility to josamycin in $M$. hominis and ureaplasmas are high [23,24], very limited in vitro data regarding josamycin susceptibility in $M$. genitalium have been published [25], which have not indicated a higher activity than azithromycin. Furthermore, no data regarding treatment efficacy of $M$. genitalium infections with josamycin have been published in the international (English language) literature. Moxifloxacin $400 \mathrm{mg}$ daily, 10 days can be used as a second-line regimen for treatment of M. genitalium infections in Russia.

The aims of this study were to examine the prevalence of M. genitalium in males attending an STI clinic in Moscow, Russia from December 2006 to January 2008, investigate the treatment efficacy with josamycin in male urethritis, and to monitor the M. genitalium DNA eradication dynamics and selection of macrolide resistance in M. genitalium during treatment of male urethritis with josamycin.

\section{Methods}

The work was performed at the Department of Molecular Diagnostics and Epidemiology, Central Research Institute for Epidemiology, Moscow, Russia.

\section{Study population}

Consecutive males $(n=320)$ attending one of the venereologist at a sexually transmitted infection (STI) clinic in Moscow, Russia, from December 2006 to January 2008, were enrolled in the study. The males attended the STI clinic due to urethral symptoms or having had unprotected sexual intercourse with new or multiple contact(s). The mean age of the males was 31 years (median age: 30 years; range: 18 to 66 years). All males signed an informed consent form, the males were clinically examined and two urethral swabs were sampled from each patient, i.e. for microscopy and PCR, respectively.

\section{Ethical approval}

Ethical approval for the study was obtained by the Central Research Institute for Epidemiology, Moscow, Russia.

\section{Laboratory diagnostics (microscopy and PCR)}

Microscopy (1000× magnification) of Gram-stained smears was performed. The presence of $\geq 5$ polymorphonuclear leucocytes (PMNL) per high power field (hpf), in at least $5 \mathrm{hpf}$, was interpreted as urethritis. For diagnosis, M. genitalium DNA was detected by the real-time PCR assay AmpliSens ${ }^{\circ}$ M.genitalium-FRT, and the AmpliSens ${ }^{\circ}$ N.gonorrhoeae-FRT, AmpliSens ${ }^{\circ}$ C.trachomatis-FRT, and AmpliSens ${ }^{\bullet}$ T.vaginalis-FRT assays (InterLabServices Ltd, Moscow, Russia) were used to diagnose other non-viral STIs. The DNA isolation and PCR assays, which have been previously evaluated, were performed in accordance with the instructions from the manufacturer (InterLabServices Ltd, Moscow, Russia) and as previously described [26-29]. 


\section{Antimicrobial treatment of patients}

In accordance with the Russian treatment guidelines, all $M$. genitalium positive patients were treated with josamycin $500 \mathrm{mg}$ three times daily, 10 days [21]. Treatment failures with the josamycin regimen were administered moxifloxacin $400 \mathrm{mg}$ daily, 10 days. Patients positive for any other STI (according to the laboratory test results) were also treated in accordance with the Russian treatment guidelines [21].

\section{Monitoring of josamycin treatment efficacy}

All $M$. genitalium positive patients that did not have any other STI, any complicated urogenital infection, or had been administered any antimicrobials in four weeks prior to enrollment, were invited for monitoring of treatment efficacy. In participating patients, one urethral swab (for microscopy) and one first-void urine specimen (for PCR) were sampled, in a standardized and quality assured manner, on treatment onset, 3rd and 8th day of treatment, and 2nd and 14th days after completed treatment. The first-void urine was collected in $50 \mathrm{~mL}$ sterile disposable plastic containers, with a calibration scale in $\mathrm{mL}$ on the wall of the container. According to instructions and using these containers, the patients collected 15-20 mL of first-void urine (predominantly morning urine and the patients should not had urinated $3 \mathrm{~h}$ before). Valid data regarding the time since last micturition was unfortunately not possible to obtain. At each visit, compliance of the therapy was ensured. To quantify the $M$. genitalium load in these clinical specimens, three in house prepared DNA calibrators based on the $\operatorname{gyr} B$ gene $\left(10^{2}, 10^{3}, 10^{4}\right.$ genome equivalents (geq)/reaction) were included in the real-time PCR assay AmpliSens ${ }^{\oplus}$ M.genitalium-FRT (InterLabService Ltd, Moscow, Russia) [26]. The $M$. genitalium concentration detected was expressed as number of geq $\left[\log _{10}\right]$ per $1 \mathrm{~mL}$ of transport media and the $M$. genitalium load in each specimen was arbitrarily categorized as low $\left(\leq 4 \mathrm{geq} / \mathrm{mL}\left[\log _{10}\right]\right)$, moderate $(>4-<6$ geq $\left./ \mathrm{mL}\left[\log _{10}\right]\right)$ or high $\left(\geq 6 \mathrm{geq} / \mathrm{mL}\left[\log _{10}\right]\right)$. The $M$. genitalium positive samples were subsequently preserved at $-70^{\circ} \mathrm{C}$, that is, prior to sequencing for identification of macrolide resistance mutations.

\section{Identification of macrolide resistance mutations}

For identification of macrolide resistance mutations, domain $\mathrm{V}$ of the 23S rRNA gene in M. genitalium was sequenced using the previously described primers Mg23S-1992F and Mg23S-2138R [18].

\section{Results}

Symptoms/signs, microscopy results and STI etiological agents in all males $(n=320)$

Among the 320 males, 222 (69.4\%) had symptoms/signs and microscopically confirmed urethritis, and 49 (15.3\%) had no symptoms/signs but microscopically verified urethritis (Table 1). Accordingly, in total 271 cases of urethritis were confirmed. C. trachomatis, M. genitalium, Neisseria gonorrhoeae and Trichomonas vaginalis was detected in 102 (37.6\%), 46 (17.0\%), 29 (10.7\%) and 9 (3.3\%), respectively, of the 271 urethritis cases. $C$. trachomatis and $M$. genitalium was also detected in eight and five, respectively, of the males lacking symptoms/signs and having $\leq 5$ PMNLs/hpf.

\section{Mycoplasma genitalium positive males}

In total, M. genitalium was detected in 51 (15.9\%) of the 320 includes males. However, four of the M. genitalium positive males were also positive for some additional STI etiological agent, that is, C. trachomatis $(\mathrm{n}=2)$, T. vaginalis $(\mathrm{n}=1)$, and Herpes simplex virus type $2(\mathrm{n}=1)$. For the treatment monitoring, these four males were excluded. However, no males were excluded due to having a complicated urogenital infection or taking antimicrobials during the four weeks prior to enrollment. Accordingly,

Table 1 Symptoms/signs, polymorphonuclear leucocytes (PMNLs), and detected STI etiological agents in males $(n=320)$ attending an STI clinic in Moscow, Russia, from December 2006 to January 2008

\begin{tabular}{|c|c|c|c|c|c|}
\hline $\begin{array}{l}\text { Clinical } \\
\text { characteristics }\end{array}$ & $\begin{array}{l}\text { Number } \\
\text { of patients }\end{array}$ & $\begin{array}{l}\text { Chlamydia trachomatis } \\
\text { positive }\end{array}$ & $\begin{array}{l}\text { Mycoplasma genitalium } \\
\text { positive }^{\text {a }}\end{array}$ & $\begin{array}{l}\text { Neisseria gonorrhoeae } \\
\text { positive }\end{array}$ & $\begin{array}{l}\text { Trichomonas vaginalis } \\
\text { positive }\end{array}$ \\
\hline Symptoms/signs and & 222 & 75 & 40 & 27 & 6 \\
\hline \multicolumn{6}{|l|}{ PMNLs $\geq 5$} \\
\hline Symptoms/signs and & 0 & 0 & 0 & 0 & 0 \\
\hline \multicolumn{6}{|l|}{ PMNLs <5 } \\
\hline No symptoms/signs and & 49 & 27 & 6 & 2 & 3 \\
\hline \multicolumn{6}{|l|}{ PMNLs $\geq 5$} \\
\hline No symptoms/signs and & 49 & 8 & 5 & 0 & 0 \\
\hline \multicolumn{6}{|l|}{ PMNLs < 5} \\
\hline Total & 320 & 110 & 51 & 29 & 9 \\
\hline
\end{tabular}

${ }^{a}$ Four patients positive for M. genitalium as well as some additional STI etiological agent, i.e. C. trachomatis $(n=2), T$. vaginalis $(n=1)$, and Herpes simplex virus type $2(n=1)$, were excluded. 
47 (14.7\%) of the 320 males were positive for M. genitalium only, which corresponded to 44 (16.2\%) of the confirmed 271 urethritis cases. Of these $47 \mathrm{M}$. genitalium positive patients, $40(85.1 \%)$ had symptoms of urethritis and $\geq 5 \mathrm{PMNL} / \mathrm{hpf}$, four (8.5\%) were asymptomatic but had $\geq 5 \mathrm{PMNL} / \mathrm{hpf}$, and three (6.4\%) had no symptoms and $<5$ PMNL/hpf. Twenty-two (46.8\%) and 15 (31.9\%) of the 47 patients had $\geq 10$ and $>50 \mathrm{PMNL} / \mathrm{hpf}$, respectively.

\section{Monitoring of treatment efficacy with josamycin}

Forty-six (97.9\%) of the 47 males positive for only $M$. genitalium agreed to participate and attended most of the visits for the monitoring of treatment efficacy with josamycin. The mean age of these participants was 30 years (median age: 30 years; range: 18 to 41 years). The results of the treatment monitoring are summarized in Table 2.

Briefly, 10 (22.2\%), 29 (64.4\%) and six (13.3\%) of the patients had a low $\left(\leq 4 \mathrm{geq} / \mathrm{mL}\left[\log _{10}\right]\right)$, moderate $(>4-<6$ geq $\left./ \mathrm{mL}\left[\log _{10}\right]\right)$ and high ( $\left.\geq 6 \mathrm{geq} / \mathrm{mL}\left[\log _{10}\right]\right)$, respectively, pre-treatment $M$. genitalium load. All the available pretreatment $M$. genitalium specimens $(n=45)$ had a wildtype $23 \mathrm{~S}$ rRNA gene sequence. After only three days of treatment, $48.9 \%(22 / 45)$ of the examined patients were $M$. genitalium negative, and after eight days of treatment $88.9 \%$ (40/45) were negative. The elimination of M. genitalium DNA was substantially faster in patients with lower pre-treatment $M$. genitalium load. For example, all the 13 (100\%) patients with low pre-treatment bacterial load were $M$. genitalium negative already after three days of treatment, and only $6.9 \%(2 / 29)$ of patients with moderate pretreatment M. genitalium load had detectable levels of $M$. genitalium DNA two days post-treatment, which was eliminated 10-14 days post-treatment. However, of the six patients with high pre-treatment $M$. genitalium load three (50\%) remained positive $10-14$ days after completed treatment (Table 2). All these three patients repeatedly assured full compliance to treatment and not having had any sexual contacts between initiation of josamycin therapy and follow up visit 10-14 days after completed treatment. Accordingly, the eradication rate with the josamycin treatment was 43/46 (93.5\%). Details regarding the three treatment failures are provided in Table 3.

\section{Treatment failures with josamycin $(n=3)$}

Briefly, at the time of diagnosis two of the three patients had severe symptoms of urethritis and high number of $\mathrm{PMNL} / \mathrm{hpf}$, however, the remaining patient was asymptomatic with $<5 \mathrm{PMNL} / \mathrm{hpf}$. In the two symptomatic patients, the symptoms and signs initially resolved. However, one of them had relapsed symptoms and signs of severe urethritis 10-14 days after treatment, which was also the case for the initially asymptomatic patient. The M. genitalium strains in all three patients had mutations in the macrolide resistance region of $23 \mathrm{~S}$ rRNA during treatment. Accordingly, the M. genitalium strains in two and one of those patients had an A2059G mutation (Escherichia coli numbering) and A2062G mutation, respectively, in the $23 \mathrm{~S}$ rRNA gene (Table 3). The patients were subsequently successfully treated with moxifloxacin $400 \mathrm{mg}$ daily, 10 days.

\section{Discussion}

In the present study, it was shown that M. genitalium is a frequent cause of male urethritis in Moscow, Russia and that the M. genitalium eradication rate in 2006-2008 was 93.5\% with the recommended first-line treatment in Russia, that is, josamycin $500 \mathrm{mg}$ three times daily, 10 days [21]. These are the first data published regarding efficacy using josamycin for treatment of $M$. genitalium infections in the international (English language) literature. Accordingly, no evidence-based data supporting josamycin, compared to e.g. azithromycin, for treatment of M. genitalium infections and exceedingly limited in vitro data regarding josamycin susceptibility in M. genitalium, have been internationally published. To our best knowledge, the only

Table 2 Eradication of Mycoplasma genitalium DNA during treatment with josamycin in 46 males with urethritis

\begin{tabular}{|c|c|c|c|c|c|c|}
\hline \multirow{2}{*}{$\begin{array}{l}\text { Bacterial load } \\
\text { pre-treatment }\end{array}$} & \multirow{2}{*}{$\begin{array}{l}\text { M. genitalium DNA } \\
\left.\text { concentration (geq/mL }\left[\log _{10}\right]\right)\end{array}$} & \multicolumn{5}{|c|}{ No. (\%) of $M$. genitalium positive patients } \\
\hline & & $0 \mathrm{~d} / \mathrm{t}$ & $3 \mathrm{~d} / \mathrm{t}$ & $8 \mathrm{~d} / \mathrm{t}$ & $2 \mathrm{~d} / \mathrm{at}$ & $10-14 \mathrm{~d} / \mathrm{at}$ \\
\hline Low & $\leq 4$ & $10(100)$ & $3(30)$ & $0(0)$ & $0(0)$ & $0(0)$ \\
\hline Moderate & $>4-<6$ & $29(100)$ & $15(51.7)^{\mathrm{b}}$ & $3(10.3)$ & $2(6.9)^{d}$ & $0(0)$ \\
\hline High & $\geq 6$ & $6(100)$ & $5(83.3)$ & $2(33.3)^{c}$ & $3(50)$ & $3(50)$ \\
\hline \multicolumn{2}{|c|}{ Total no. of patients examined } & $45^{\mathrm{a}}$ & 45 & 45 & 45 & $14^{e}$ \\
\hline
\end{tabular}

$\mathrm{geq} / \mathrm{mL}\left(\log _{10}\right), \log _{10}$ of genome equivalents $/ \mathrm{mL} ; \mathrm{d} / \mathrm{t}$, days of treatment; $\mathrm{d} / \mathrm{at}$, days after completed treatment.

${ }^{a}$ Sample from one patient was not available. At $3 \mathrm{~d} / \mathrm{t}$, this patient had $3.1 \mathrm{geq} / \mathrm{mL}\left[\log _{10}\right]$, and at the three subsequent visits he was $M$. genitalium negative.

${ }^{b}$ Sample from one patient was not available. This patient was asymptomatic, $M$. genitalium negative but demonstrated microscopic signs of urethritis on the three subsequent visits.

'Sample from one patient was not available. This was treatment failure A, see Table 3.

${ }^{d}$ Sample from one patient was not available. The patient reported to be asymptomatic on the phone and at $3 \mathrm{~d} / \mathrm{t}$ and $8 \mathrm{~d} / \mathrm{t}$, no symptoms, signs or $\mathrm{M}$. genitalium DNA was detected.

${ }^{e}$ Thirty-two patients did not attend. However, all of the non-attending patients were $M$. genitalium negative already at earlier visits (both at $8 \mathrm{~d} / \mathrm{t}$ and $2 \mathrm{~d} / \mathrm{at}$ ) and also reported to be completely asymptomatic on phone. 
Table 3 Details of three failures to treat Mycoplasma genitalium urethritis with josamycin, including bacterial load in $\log _{10}$ genome equivalents/mL (23S rRNA gene), symptoms and microscopy results at different visits

\begin{tabular}{|c|c|c|c|c|c|c|}
\hline Patients & Sexual orientation & $0 \mathrm{~d} / \mathrm{t}$ & $3 \mathrm{~d} / \mathrm{t}$ & $8 \mathrm{~d} / \mathrm{t}$ & $2 \mathrm{~d} / \mathrm{at}$ & $10-14 \mathrm{~d} / \mathrm{at}$ \\
\hline \multirow[t]{2}{*}{ Case $A^{a}$} & Heterosexual & 6.4 (WT) & 4.7 (WT) & NA & 2.1 (A2059G) & 3.2 (A2059G) \\
\hline & & $\begin{array}{l}\text { Severe urethritis } \\
\text { symptoms, 25-30 } \\
\text { PMNL/hpf }\end{array}$ & $\begin{array}{l}\text { Less severe urethritis } \\
\text { symptoms, 10-15 } \\
\text { PMNL/hpf }\end{array}$ & $\begin{array}{l}\text { Mild itching only, } \\
\text { 2-3 PMNL/hpf }\end{array}$ & $\begin{array}{l}\text { Asymptomatic, } \\
<5 \mathrm{PMNL} / \mathrm{hpf}\end{array}$ & $\begin{array}{l}\text { Asymptomatic, } \\
<5 \mathrm{PMNL} / \mathrm{hpf}\end{array}$ \\
\hline \multirow[t]{2}{*}{ Case $B^{a}$} & Heterosexual & $6.2(\mathrm{WT})$ & 2.5 (WT) & $0.8(\mathrm{NA})$ & 2.0 (A2062G) & 1.9 (A2062G) \\
\hline & & $\begin{array}{l}\text { Severe urethritis } \\
\text { symptoms, } 60 \\
\text { PMNL/hpf }\end{array}$ & $\begin{array}{l}\text { Less severe urethritis } \\
\text { symptoms, 20-30 } \\
\text { PMNL/hpf }\end{array}$ & $\begin{array}{l}\text { Mild discharge } \\
\text { and itching, } \\
\text { 15-20 PMNL/hpf }\end{array}$ & $\begin{array}{l}\text { Asymptomatic, } \\
\text { 10-12 PMNL/hpf }\end{array}$ & $\begin{array}{l}\text { Severe urethritis } \\
\text { symptoms, } 100 \mathrm{PMNL} / \mathrm{hpf}\end{array}$ \\
\hline \multirow[t]{2}{*}{ Case $C^{a}$} & Heterosexual & $7.2(\mathrm{WT})$ & 7.0 (WT) & 4.3 (WT) & 5.0 (A2059G) & 7.5 (A2059G) \\
\hline & & $\begin{array}{l}\text { Asymptomatic, } \\
<5 \mathrm{PMNL} / \mathrm{hpf}\end{array}$ & $\begin{array}{l}\text { Asymptomatic, } \\
<5 \mathrm{PMNL} / \mathrm{hpf}\end{array}$ & $\begin{array}{l}\text { Asymptomatic, } \\
<5 \mathrm{PMNL} / \mathrm{hpf}\end{array}$ & $\begin{array}{l}\text { Asymptomatic, } \\
<5 \mathrm{PMNL} / \mathrm{hpf}\end{array}$ & $\begin{array}{l}\text { Severe urethritis } \\
\text { symptoms, 40-60 } \\
\text { PMNL/hpf }\end{array}$ \\
\hline
\end{tabular}

$\mathrm{d} / \mathrm{t}$, days of treatment; $\mathrm{d} /$ at, days after completed therapy; WT, wild-type $23 \mathrm{~S}$ rRNA gene sequence; NA, not assessed (specimen not available and too low concentration of $M$. genitalium DNA for $23 \mathrm{~S}$ rRNA gene sequencing, respectively); PMNL/hpf, polymorphonuclear leucocytes/high power field.

${ }^{a}$ All three patients repeatedly reassured that they had not had any unprotected sexual contacts between initiation of the josamycin treatment and test of cure. All patients were subsequently successfully treated with moxifloxacin $400 \mathrm{mg}$ single oral dose daily in 10 days, which was confirmed by lack of symptoms, signs and M. genitalium DNA at follow up visit four weeks after the treatment.

in vitro antimicrobial susceptibility data were published in 1992 (only seven isolates were tested) and the activity was slightly lower compared to azithromycin [25]. In the present study, it was also shown that josamycin resistance resulting in treatment failures can rapidly be selected during treatment. The eradication rate of $M$. genitalium after the internationally widely used azithromycin $1 \mathrm{~g}$ therapy has substantially declined during the last decade $[1,10,12-14,16]$. Treatment with azithromycin $1 \mathrm{~g}$ was also recently associated with selection of macrolide resistant M. genitalium [14], and it was also hypothesized that treatment failures are frequently associated with a higher load of M. genitalium [17]. The results of the present study, instead examining the macrolide josamycin, are in full concordance with these recent findings. Accordingly, three failures to treat male $M$. genitalium urethritis with josamycin were verified. All of these patients had a high pre-treatment $M$. genitalium load ( $>6$ geq $/ \mathrm{mL}$ $\left.\left[\log _{10}\right]\right)$ and $M$. genitalium cells with mutations in the macrolide resistance-determining region $\mathrm{V}$ of $23 \mathrm{~S}$ rRNA $[1,10,13,14,18]$ were selected during treatment. Thus, despite that no 23S rRNA gene mutations were identified in the pre-treatment $M$. genitalium specimens the term selected resistance instead of induced resistance was used in the present study. Accordingly, it was considered that an undetected minority population of macrolide resistant $M$. genitalium cells might have been present already pre-treatment. These resistant cells, in the specimens with high $M$. genitalium load, could subsequently be selected during treatment with the bacteriostatic josamycin. The probability of this selection scenario was considered higher particularly because it is unknown how frequently josamycin might be able to directly induce $23 \mathrm{~S}$ rRNA gene mutations, especially during treatment of M. genitalium with a very long generation time. The three identified treatment failures were further supported by the rebound in $M$. genitalium loads in all three patients and the recrudescence of symptoms in two of the three patients. Thus, the pre-treatment M. genitalium load might be an effective predictor of eradication efficacy with macrolides (and possibly additional antimicrobials) and selection of macrolide resistance due to mutations in the $23 \mathrm{~S}$ rRNA gene. Unambiguously, additional data are crucial to support the recommendation of using josamycin regimen as first-line treatment in the Russian treatment guidelines for M. genitalium infections.

The most frequent 23S rRNA mutations identified in M. genitalium strains resistant to the 15-membered macrolide azithromycin have been A2058G and A2059G $[1,13,14,17,18,30,31]$. In the present study, it was for the first time shown that the A2059G mutation is associated also with $M$. genitalium resistance to 16-membered macrolides, e.g. josamycin. It has been earlier demonstrated that the A2059G mutation results in high-level resistance to 16 -membered macrolides in the closely related species M. pneumoniae [32]. The A2062G mutation found in the remaining treatment failure has not been previously described in $M$. genitalium. However, M. hominis and M. pneumoniae cells with A2062G and A2062T mutations in the 23S rRNA gene have been previously selected in vitro using josamycin and shown to cause high-level josamycin resistance [33,34]. Interestingly, previous studies have suggested that mutations in the A2062 position of the 23S rRNA gene result in resistance to the 16-membered macrolides (e.g., josamycin), but not necessarily to the 15-membered macrolides (e.g., azithromycin), indicating a slightly different binding site [35-37]. 
In M. pneumoniae, the A2062G mutation, detected after in vitro exposure of josamycin, has also been shown to significantly increase the MICs of the streptogramin pristinamycin [34]. This is of grave concern because pristinamycin is highly active against $M$. genitalium infections and currently the only treatment option for infections resistant to both azithromycin and moxifloxacin [38]. Nevertheless, it remains unknown if an A2058G/A2059G mutation (resulting in azithromycin resistance) and an A2062G mutation (resulting in resistance to pristinamycin (and josamycin)) can co-exist in the 23S rRNA gene of M. genitalium, i.e. without severely decreasing the biological fitness and possibilities for transmission of the M. genitalium strain.

\section{Conclusions}

In the present study, it was shown that M. genitalium is a frequent cause of male urethritis in Moscow, Russia. Furthermore, the first data on efficacy using josamycin for treatment of M. genitalium urethritis were also presented (93.5\% eradication rate). All the three verified treatment failures had a high pre-treatment M. genitalium load and cells with mutations in the macrolide resistance region of $23 \mathrm{~S}$ rRNA were easily selected during treatment. Because the present study examined material from December 2006 to January 2008 and the population selective pressure for resistance due to wide usage of macrolides has been very large and selected for relatively high-levels of azithromycin resistance in many countries during the recent decade, it is crucial to examine the josamycin treatment efficacy and M. genitalium load, including cut-off for possible treatment failure, as well as to screen for resistance to macrolides (and other antimicrobials) in a more recent material of M. genitalium positive clinical specimens (pre- and post-treatment) in Russia. This should ideally include both genetic screening for macrolide resistance mutations (previously described and novel), moxifloxacin resistance mutations and culture of $M$. genitalium, including MIC determination for macrolides (including azithromycin and josamycin), moxifloxacin and pristinamycin to confirm the phenotypic effects of the mutations on the antimicrobial resistance. No evidence-based data supporting josamycin, compared to e.g. azithromycin, for treatment of M. genitalium infections and exceedingly limited in vitro data regarding josamycin susceptibility in M. genitalium, have been internationally published [25]. Accordingly, additional in vivo and in vitro data are crucial to support the currently recommended josamycin regimen as first-line treatment in the Russian treatment guidelines for M. genitalium infections. It would be valuable to develop and implement international guidelines for management of M. genitalium infections and the results of the present study indicate that quantitative diagnostic PCRs determining also $M$. genitalium load and resistance mutations (for macrolides and ideally also moxifloxacin) should ideally be recommended for diagnosis of $M$. genitalium infections. Finally, novel options for effective treatment of M. genitalium infections are essential and dual antimicrobial therapy, which has been introduced for gonorrhoea, might need to be considered also for M. genitalium infections.

\section{Competing interests}

The authors declare that they have no competing interests.

\section{Authors' contributions}

$A G, M G$ and $M U$ designed, initiated and coordinated the study. AG, PR, TR, and $M G$ coordinated and performed all the laboratory analyses. AG and MU analysed and interpreted all the data, and wrote a first draft of the paper. All authors read, commented and approved the final manuscript.

\section{Acknowledgements}

The present work was supported by the Central Research Institute for Epidemiology, Moscow, Russia.

\section{Author details}

${ }^{1}$ Department of Molecular Diagnostics and Epidemiology, Central Research Institute for Epidemiology, Moscow, Russia. ${ }^{2}$ Moscow Scientific and Practical Center for Dermatovenerology and Cosmetology, Moscow, Russia. ${ }^{3} \mathrm{WHO}$ Collaborating Centre for Gonorrhoea and other STIs, National Reference Laboratory for Pathogenic Neisseria, Örebro University Hospital, Örebro, Sweden. ${ }^{4}$ Department of Laboratory Medicine, Microbiology, School of Medicine, Örebro University, Örebro, Sweden.

Received: 3 November 2014 Accepted: 23 January 2015

Published online: 03 February 2015

\section{References}

1. Taylor-Robinson D, Jensen JS. Mycoplasma genitalium: from Chrysalis to multicolored butterfly. Clin Microbiol Rev. 2011;24:498-514.

2. Cohen CR, Manhart LE, Bukusi EA, Astete S, Brunham RC, Holmes KK, et al. Association between Mycoplasma genitalium and acute endometritis. Lancet. 2002;359:765-6.

3. Manhart LE, Critchlow CW, Holmes KK, Dutro SM, Eschenbach DA, Stevens CE, et al. Mucopurulent cervicitis and Mycoplasma genitalium. J Infect Dis. 2003;187:650-7.

4. Cohen CR, Mugo NR, Astete SG, Odondo R, Manhart LE, Kiehlbauch JA, et al. Detection of Mycoplasma genitalium in women with laparoscopically diagnosed acute salpingitis. Sex Transm Infect. 2005;81:463-6.

5. Anagrius C, Loré B, Jensen JS. Mycoplasma genitalium: prevalence, clinical significance, and transmission. Sex Transm Infect. 2005;81:458-62.

6. Bjartling C, Osser S, Persson K. Mycoplasma genitalium in cervicitis and pelvic inflammatory disease among women at a gynecologic outpatient service. Am J Obstet Gynecol. 2012;206:476-8.

7. Andersen B, Sokolowski I, Østergaard L, Kjølseth Møller J, Olesen F, Jensen JS. Mycoplasma genitalium: prevalence and behavioural risk factors in the general population. Sex Transm Infect. 2007;83:237-41.

8. Oakeshott P, Aghaizu A, Hay P, Reid F, Kerry S, Atherton H, et al. Is Mycoplasma genitalium in women the "New Chlamydia?" A community-based prospective cohort study. Clin Infect Dis. 2010;51:1160-6.

9. Shahmanesh M, Moi H, Lassau F, Janier M. IUSTI/WHO: European guideline on the management of male non-gonococcal urethritis. Int J STD AIDS. 2009;20:458-64.

10. Manhart LE, Gillespie CW, Lowens MS, Khosropour CM, Colombara DV, Golden MR, et al. Standard treatment regimens for nongonococcal urethritis have similar but declining cure rates: A randomized controlled trial. Clin Infect Dis. 2013;56:934-42.

11. Björnelius $E$, Anagrius C, Bojs G, Carlberg H, Johannisson G, Johansson E, et al. Antibiotic treatment of symptomatic Mycoplasma genitalium infection in Scandinavia: a controlled clinical trial. Sex Transm Infect. 2008;84:72-6.

12. Mena LA, Mroczkowski TF, Nsuami M, Martin DH. A randomized comparison of azithromycin and doxycycline for the treatment of Mycoplasma genitalium-positive urethritis in men. Clin Infect Dis. 2009;48:1649-54. 
13. Salado-Rasmussen K, Jensen JS. Mycoplasma genitalium testing pattern and macrolide resistance: a Danish nationwide retrospective survey. Clin Infect Dis. 2014;59:24-30.

14. Anagrius C, Lore B, Jensen JS. Treatment of Mycoplasma genitalium. Observations from a Swedish STD clinic PLOS ONE. 2013;8:e61481.

15. Jernberg E, Moghaddam A, Moi H. Azithromycin and moxifloxacin for microbiological cure of Mycoplasma genitalium infection: an open study. Int J STD AIDS. 2008;19:676-9.

16. Schwebke JR, Rompalo A, Taylor S, Seña AC, Martin DH, Lopez LM, et al. Re-evaluating the treatment of nongonococcal urethritis: emphasizing emerging pathogens - a randomized clinical trial. Clin Infect Dis. 2011;52:163-70.

17. Walker J, Fairley CK, Bradshaw CS, Tabrizi SN, Twin J, Chen MY, et al. Mycoplasma genitalium incidence, organism load, and treatment failure in a cohort of young Australian women. Clin Infect Dis. 2013;56:1094-100.

18. Jensen JS, Bradshaw CS, Tabrizi SN, Fairley CK, Hamasuna R. Azithromycin treatment failure in Mycoplasma genitalium-positive patients with nongonococcal urethritis is associated with induced macrolide resistance. Clin Infect Dis. 2008:47:1546-53.

19. Couldwell DL, Tagg KA, Jeoffreys NJ, Gilbert GL. Failure of moxifloxacin treatment in Mycoplasma genitalium infections due to macrolide and fluoroquinolone resistance. Int J STD AIDS. 2013;24:822-8.

20. Manhart LE, Khosropour CM, Gillespie CW, Lowens MA, Golden MR, Totten PA. Treatment outcomes for persistent Mycoplasma genitalium associated NGU: evidence of moxifloxacin treatment failures. Sex Transm Infect. 2013;89 suppl 1:A29.

21. Clinical practice guidelines for management of patients with sexually transmitted infections and reproductive tract infections // Moscow, Russia, 2012. Izdatel'skiy dom Delovoy ekspress. - 112 S (In Russian).

22. Lanjouw E, Ossewaarde JM, Stary A, Boag F, van der Meijden WI. European guideline for the management of Chlamydia trachomatis infections. Int J STD AIDS. 2010;21:729-37.

23. Krausse R, Schubert S. In-vitro activities of tetracyclines, macrolides, fluoroquinolones and clindamycin against Mycoplasma hominis and Ureaplasma ssp. isolated in Germany over 20 years. Clin Microbiol Infect. 2010:16:1649-55.

24. Song T, Ye A, Xie X, Huang J, Ruan Z, Kong Y, et al. Epidemiological investigation and antimicrobial susceptibility analysis of ureaplasma species and Mycoplasma hominis in outpatients with genital manifestations. J Clin Pathol. 2014;67:817-20.

25. Renaudin H, Tully JG, Bebear C. In vitro susceptibilities of Mycoplasma genitalium to antibiotics. Antimicrob Agents Chemother. 1992:36:870-2.

26. Shipitsyna E, Zolotoverkhaya E, Dohn B, Benkovich A, Savicheva A, Sokolovsky $E$, et al. First evaluation of polymerase chain reaction assays used for diagnosis of Mycoplasma genitalium in Russia. J Eur Acad Dermatol Venereol. 2009;23:1164-72.

27. Shipitsyna E, Zolotoverkhaya E, Agné-Stadling I, Krysanova A, Savicheva A, Sokolovsky E, et al. First evaluation of six nucleic acid amplification tests (NAATs) widely used in the diagnosis of Chlamydia trachomatis in Russia. J Eur Acad Dermatol Venereol. 2009;23:268-76.

28. Shipitsyna E, Zolotoverhaya E, Hjelmevoll SO, Maximova A, Savicheva A,

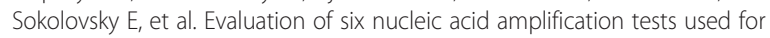
diagnosis of Neisseria gonorrhoeae in Russia compared with an international strictly validated real-time porA pseudogene polymerase chain reaction. J Eur Acad Dermatol Venereol. 2009;23:1246-53.

29. Shipitsyna E, Zolotoverkhaya E, Chen CY, Chi KH, Grigoryev A, Savicheva A, et al. Evaluation of polymerase chain reaction assays for the diagnosis of Trichomonas vaginalis infection in Russia. J Eur Acad Dermatol Venereol. 2013;27:e217-23

30. Pond MJ, Nori AV, Witney AA, Lopeman RC, Butcher PD, Sadiq ST. High prevalence of antibiotic-resistant Mycoplasma genitalium in non-gonococcal urethritis: the need for routine testing and the in adequacy of current treatment options. Clin Infect Dis. 2014;58:631-7.

31. Tagg KA, Jeoffreys NJ, Couldwell DL, Donald JA, Gilbert GL. Fluoroquinolone and macrolide resistance-associated mutations in Mycoplasma genitalium. J Clin Microbiol. 2013:51:2245-9.

32. Lucier TS, Heitzman K, Liu SK, Hu PC. Transition mutations in the $23 \mathrm{~S}$ rRNA of erythromycin-resistant isolates of Mycoplasma pneumoniae. Antimicrob Agents Chemother. 1995;39:2770-3.

33. Furneri PM, Rappazzo G, Musumarra MP, Di Pietro P, Catania LS, Roccasalva LS. Two new point mutations at A2062 associated with resistance to 16-membered macrolide antibiotics in mutant strains of Mycoplasma hominis. Antimicrob Agents Chemother. 2001:45:2958-60.

34. Pereyre S, Guyot C, Renaudin H, Charron A, Bébéar C, Bébéar CM. In vitro selection and characterization of resistance to macrolides and related antibiotics in Mycoplasma pneumoniae. Antimicrob Agents Chemother. 2004:48:460-5.

35. Garza-Ramos G, Xiong L, Zhong P, Mankin A. Binding site of macrolide antibiotics on the ribosome: new resistance mutation identifies a specific interaction of ketolides with rRNA. J Bacteriol. 2001;183:6898-907.

36. Hansen JL, Ippolito JA, Ban N, Nissen P, Moore PB, Steitz TA. The structures of four macrolide antibiotics bound to the large ribosomal subunit. Mol Cell. 2002;10:117-28.

37. Depardieu F, Courvalin P. Mutation in $23 \mathrm{~S}$ rRNA responsible for resistance to 16-membered macrolides and streptogramins in Streptococcus pneumoniae. Antimicrob Agents Chemother. 2001:45:319-23.

38. Bissessor M, Tabrizi SN, Twin J, Abdo H, Fairley CK, Chen MY, Vodstrcil LA, Jensen JS, Hocking JS, Garland SM, Bradshaw CS: Macrolide resistance and azithromycin failure in a Mycoplasma genitalium-infected cohort, and response of azithromycin failures to alternative antibiotic regimens. Clin Infect Dis 2014 Dec 23. [Epub ahead of print]

\section{Submit your next manuscript to BioMed Central and take full advantage of:}

- Convenient online submission

- Thorough peer review

- No space constraints or color figure charges

- Immediate publication on acceptance

- Inclusion in PubMed, CAS, Scopus and Google Scholar

- Research which is freely available for redistribution 